\title{
ТВОРЧА СПІВПРАЦЯ СВЯТОСЛАВА КРУТИКОВА ТА ГЕННАДІЯ САСЬКА В РАМКАХ ХІ МУЗИЧНОГО ФЕСТИВАЛЮ “СТРУНИ ДУШ НАШОЇ”
}

записки Бердянського державного педагогічного університету. Серія : Педагогіка : зб. наук. пр. - Бердянськ: ФО-П Ткачук О.В., 2017.-Вип. 1.-С. $262-268$.

\section{REFERENCES}

1. Zyazyun, I. A. \& Sahach G. M. (1997). Krasa pedahohichnoyi diyi [The beauty of Pedagogical Idea]. Kyiv, Ukrainian-Finnish Institute of Management and Business, p.4. [in Ukrainian].

2. Pavlenko, V. V. (2011). Problemy pedahohichnoyi maysternosti vchytelya u spadshchyni vydatnykh pedahohiv [Problems of Pedagogical Mastery of a Teacher in the Heritage of Outstanding Teachers]. Professionalcompetent attitude of future teachers of elementary and pre-school education in higher educational institutions: a collection of scientific and methodical works. Zhytomyr,
(Ed). V.E. Litnova, N.E. Chariot. Publ., of ZhSU named after I. Franko, 304 p., pp.216-224. [in Ukrainian].

3. Belcheva, T. F., Izbash S. S., Elkin, M.V. et al. (2010). Pedahohichna maysternist suchasnoho vchytelya: teoriya i praktyka [Pedagogical skill of a modern teacher: theory and practice]. Textbook on credit-modular technology of training for bachelors. Melitopol: LLC Publishing House MMD, pp. 273-274. [in Ukrainian].

4. Zyazyun, I. A., Kramuschenko, L. V., Kryvonos, I.F. et al. (1997). Pedahohichna maysternist [Pedagogical skills: Textbook]. Kyiv. High School, 349 p. [in Ukrainian].

5. Petko, L.V. (2017). Vykhovannya estetychnoyi kultury studentiv v umovakh universytetu [Education of the aesthetic culture of the students of the university]. Scientific notes of the Berdyansk State Pedagogical University. Series: Pedagogy. Science works. Berdyansk, vol.1, pp. 262-268. [in Ukrainian].

Стаття надійшла до редакції 06.08.2018

УДК 78. 071.1(477)

DOI:

Уляна Молчко, доцент кафедри музикознавства та фортепіано Дрогобицького державного педагогічного університету імені Івана Франка

\section{ТВОРЧА СПІВПРАЦЯ СВЯТОСЛАВА КРУТИКОВА ТА ГЕННАДІЯ САСЬКА В РАМКАХ ХІ МУЗИЧНОГО ФЕСТИВАЛЮ “СТРУНИ ДУШІ НАШОЇ”}

Дослідження розглядає мистеџькі здобутки сучасних украйнських композиторів Святослава Крутикова і Геннадія Саська, з якими галицька культурно-освітня громадськість познайомилася в рамка ХІ музичного фестивалю “Струни душі нашої”. Автор статті аналізує творчі доробки фундаторів національної культури, їх художні експерименти, жанрове різноманіття, стилістичне багатство. У публікації фіксується артистичні персоналї, котрі взяли участь у конщертних проектах, здійснюється аналіз інтерпретацій виконавиів.

Ключові слова: С. Крутиков; Г. Сасько; музичний фестиваль; м. Дрогобич; інтерпретачія.

Jim. 6.

Ulyana Molchko, Associate Professor of the Musicology and Piano Department Drohobych Ivan Franko State Pedagogical University

\section{CREATIVE COOPERATION OF SVYATOSLAV KRUTYKOV AND HENNADIY SASKO IN THE FRAMES OF THE FOURTH MUSIC FESTIVAL “THE STRINGS OF OUR SOUL"}

The research examines the artistic achievements of contemporary Ukrainian composers Svyatoslav Krutykov and Hennadiy Sasko, who entered the arena of Galician cultural and educational community in the framework of the XI musical festival "The Strings of Our Soul". The author analyzes the creative projects of the founders of the national culture, their artistic experiments, genre diversity, and stylistic wealth.

In conducting an all-round review of the 2016 art events held in Galicia, the author scientifically reflects upon the great educational work of the Drohobych organization of the National Union of Composers of Ukraine, which is famous for numerous meetings with prominent architects of the contemporary cultural space. Since 1993, within the frames of the musical festival "The Strings of Our Soul", the concert-portraits of renowned contemporary composers have been held: Mykola Kolessa, Bohdana Filts, Hennadiy Lyashenko, Yevhen Stankovych, Myroslav Skoryk, Lesya Dychko, Mykhaylo Stepanenko, Hennadiy Sasko, Yuriy Sydoryak, Oleksandr Opanasyuk, Mykola Lastovetskiy, Juliusz Juciuk (Poland), Vitaly Godziatskyi, Merziye Khalitova and others. The XI festival "The Strings of Our Soul" hospitably entertained Kyiv composers Svyatoslav Krutykov and Hennadiy Sasko.

The work documents the artists who have participated in concert projects. Namely, the teachers and students of the Drohobych Ivan Franko State Pedagogical University, Drohobych Vasyl Barvinskiy Musical College, Ostap Nyzhankivskiy Children's Music School of Stryi, Roman Savytskiy Children's Art School of Truskavets. The interpretation features by the Galician musicians of the works of S. Krutykov and H. Sasko are described.

The author proves that the meetings of the Kyiv composers S. Krutykov and H. Sasko in Galicia demonstrated 


\section{ТВОРЧА СПІВПРАЦЯ СВЯТОСЛАВА КРУТИКОВА ТА ГЕННАДІЯ САСЬКА В РАМКАХ ХІ МУЗИЧНОГО ФЕСТИВАЛЮ “СТРУНИ ДУШІ НАШОӤ”}

the dynamic creative process of the artists taking place in the coordinates of spiritual liberation, which ensures the creation of contemporary, national cultural values of great artistic worth.

Keywords: S. Krutykov; H. Sasko; musical festival; Drohobych; an interpretation.

П остановка проблеми. Музичний фестиваль “Струни душі нашої”, який проводить Дрогобицька організація Національної спілки композиторів України, славиться багаточисленними зустрічами 3 визначними творцями сьогочасного культурного простору. Починаючи з 1993 року, в рамках цього мистецького форуму відбувалися авторські концерти славетних сучасних композиторів: Миколи Колесси, Богдани Фільц, Геннадія Ляшенка, Євгена Станковича, Мирослава Скорика, Лесі Дичко, Михайла Степаненка, Геннадія Саська, Юрія Сидоряка, Олександра Опанасюка, Миколи Ластовецького, Юліуша Луцюка (Польща), Віталія Годзяцького, Мерзіє Халітової та інших. ХІ фестиваль “Струни душі нашої” гостинно приймав київських композиторів Святослава Крутикова і Геннадія Саська. Але ця яскрава мистецька сторінка в галицькому культурному просторі $\epsilon$ ще мало висвітлена.

Аналіз останніх досліджень. Артпрем'єри українських митців у Франковому краю були представлені у дописах О. Німилович [4], Т. Думан [1], Л. Тиченко [6].

Мета дослідження - здійснити наукове осмислення та мистецтвознавчий огляд авторських концертів, що відбулися в рамках XI музичного фестивалю “Струни душі нашої".

Виклад основного матеріалу. Сучасний національний культурно-освітній простір відзначається великою активністю в галузі фестивальної практики, “яка сьогодні залишається чи не єдиною і найбільш доступною формою участі населення у процесі знайомства зі зразками культури загалом, а в творчому контексті виступає однією з важливих форм самореалізації організаторів та учасників" [3, 114]. Власне тому справжнім відкриттям для галицької мистецької громади стала багатогранна творчість Святослава Крутикова - українського композитора, музиканта, художника, члена Національної спілки композиторів України та Національної спілки кінематографістів України. У час глобалізаційних процесів, легкодоступного інформаційного простору, стрімкого розвитку комп'ютерних технологій він ще, на жаль, малознаним в українській культурі. Що ж $є$ цьому причиною? Відповідь на запитання дає сам маестро, "визначаючи себе як неформат, розуміючи це як територію свободи” [2]. Таке прагнення до свободи стосується усього його життєвого та творчого шляху. Святослав
Крутиков увійшов до когорти митцівшістдесятників, серед яких - київські композитори Валентин Сильвестров, Леонід Грабовський, Віталій Годзяцький, Володимир Загорцев та інші. Здійснивши прорив унаціональній культурі періоду хрущовської “відлиги”, вони вийшли за межі соціалістичного реалізму, змінивши свої стилістичні орієнтири в сторону культуротворчих процесів європейської музики ХХ століття. Саме авангард, як найрадикальніший прояв провідного на той час у світі модерного світогляду, спонукав ïх до створення нових за змістом і виразовими засобами музичних творів.

С. Крутиков, як композитор, пройшов шлях становлення у класі композиції Бориса Лятошинського, навчаючись в Київській державній консерваторії ім. П. Чайковського. Святослав Кругиков опинився серед талановитих композиторів, що утворювали так звану групу “київського авангарду". Але хрущовська “відлига" змінилася на переслідування прогресивної творчої молоді. Не бажаючи пристосовуватися до тогочасної “задушливої” політичної атмосфери, що панувала в стінах Київської державної консерваторії ім.П. Чайковського, Крутиков кидає навчання на омріяному композиторському факультеті, позбавивши себе можливості отримати документ про музичну освіту.

Але це не стало для нього перешкодою на шляху творення свого індивідуального мистецького розвитку. Його композиторський потенціал знайшов вираження у написанні музики до більше як 50 науково-популярних фільмів, якот: “Акварелі Києва”, “Іван Франко”, “Автографи Давньої Русі”, "Реріх", “Архітектура і природа”, “Жінки Чорнобиля” та інші. Пошуки у створенні звукового тла для кіно виробило в нього вміння писати в різних стилях, змусило шукати нові акустичні можливості. Власне це, на думку Олени Зінькевич, “сприяло появі в житті Крутикова двох важливих творчих векторів. Перший - в сфері композиції: робота в галузі конкретної(з розвитком ідей П'єра Анрі і П'єра Шеффера), а згодом електроакустичної музики" [2].

Ще одним творчим захопленням композитора стало виготовлення старовинних інструментів епохи бароко та гра на них, що спонукало до заняття історичним виконавством. Це покликало до створення Крутиковим низки ансамблів давньої музики: "Ренесанс" (1980р.), "Camerata Taurica”(1986 - 1994 pp.), “Творча лабораторія 


\section{ТВОРЧА СПІВПРАЦЯ СВЯТОСЛАВА КРУТИКОВА ТАГЕННАДІЯ САСЬКА В РАМКАХ ХІ МУЗИЧНОГО ФЕСТИВАЛЮ “СТРУНИ ДУШІ НАШОӤ”}

старовинної музики" при Києво-Могилянській академії (1994 - 2000 рр.).

Повертаючись до аналізу музичної творчості, потрібно відзначити ії оригінальну багатожанрову палітру. Це - кантата “Слово про Ігорів похід” для баса, читця та ансамблю старовинних інструментів (1985р.), “Jhana” для трьох флейт (1965 р.), “Стереомузика №1”- для флейти, арфи, фортепіано та дзвіночків (1982 р.), “Стереомузика №2” - для голосу (сопрано) та 10-ти виконавців (1983 р.) “Стереомузика №3”,-- для сопрано та 18-ти виконавців (1988р.); “Зупинки на шляху в чотирьох молитвах" для саксофона і квартету флейт (1996р.); маленькі камерні симфонії “Валерію Шевчуку” (1996 р.), “Два слова” (2002 р.); для клавесину - “П'ять спогадів” (2005 р.), “10 світлин маленької мавпочки” (2007р.); для фортепіано - “Три спалахи у громовиці” (1997 р.), “Одинадцять віршів про те саме” (1998р.); для баритона, фортепіано, скрипки та віолончелі- "Три Apiï” (2000 p., на сл. Дж. Кітса - також мовою оригіналу); для гобою соло в катедральній акустиці - “Три Янголи” (2001р.); “Медитація пам'яті В. Раєвського для аудіофайлу та скрипки” (2010 р.). Його композиціям, як зазначає Михайло Степаненко, “притаманні лаконічність, камерність форми, персоналізованість інструментальних партій навіть у великих складах" [5].

Ще одним провідним вектором творчості Святослава Крутикова є живопис. Його перу належать картини: “Храм”, “Ангел”, “Античні сни”, “Осінній концерт”, “Чернетка симфонії”, “Відпочинок піаніста”, “Старовинна музика”.

Усе своє багатовекторне творче надбання представив Святослав Крутиков на фестивалі української музики “Струни душі нашої” у франковім краю. 4 травня 2016 року в актовій залі Дрогобицького державного педагогічного університету імені Івана Франка відбувся авторський концерт київського композитора, який зібрав чималу мистецьку аудиторію. У вступному слові В. Грабовський наголосив на складному шляху зародження та розвитку національної електронної музики, патріархом якої є Святослав Крутиков, а також ознайомив присутніх 3 перипетіями життєвого шляху, окремими творчими віхами митця-шістдесятника.

Зворушливу та ніжну атмосферу підкреслили музичні номери. Розпочала концертну програму “Медитація пам'яті В. Раєвського для аудіофайлу та скрипки”, яку виконав викладач-методист Дрогобицького державного музичного училища ім. В. Барвінського, скрипаль Іриней Турканик. Цей твір присвячений Валентину Раєвському (1956 - 2010 рр.) - художнику-авангардисту, архітектору, громадському діячу. Його творчість насичена глибокою духовністю. Власне тому С. Крутиков, змальовуючи митця, застосовує жанр медитації. Ці музичні роздуми композитора тонко відчув та передав у своїй грі I. Турканик. Його виконання відзначалося заглибленістю в мелодичний тематизм п'єси, чіткою ритмічністю та тонким динамічним нюансуванням. Зачарувало слухачів по-особливому індивідуальне відчуття скрипалем часопросторових особливостей твору, що підкреслило духовнообразну сторону композиції.

Сюїта “П’ять спогадів для клавесину” у виконанні викладача-методиста Дрогобицького державного музичного училища ім. В. Барвінського Олени Дмитрієвої прозвучала на старовинному інструменті. Вона також високохудожньо передала неоромантичну стильову спрямованість циклу в програмних п’єсах: “Сон”, “Такі далекі зірки”, “Така приємна зустріч”, "Чудова кримська ніч”, “Пригадування сну”. Грі О. Дмитрієвої була властива акварельність, фактурна прозорість, проникливе заглиблення в домінуючу ліричну образну сферу творів.

“Три обіцянки для трьох інструментів” представив концертній аудиторії студентський колектив Дрогобицького державного музичного училища ім. В. Барвінського у складі Нелі Ковалишин (фортепіано, клас викладача Р. Бурди), Богдана Гроса (флейта, клас викладача Я. Соляра), ПетраМельника (саксофон, клас викладача Я. Проціва). Притаманна їм м'якість та гнучкість ансамблевого виконавства сприяла передачі імпровізаційного звучання кожної мелодичної лінії.

Слухацька аудиторія мала унікальну нагоду почути один із останніх опусів композитора - твір “Зоряна людина Клим Чурюмов”. Бажання митця увічнити для нащадків видатного сучасного українського астронома, першовідкривача комет Чурюмов-Герасименко, Чурюмов-Солодовникова, члена-кореспондента Національної академії наук України Клима Чурюмова (1937 р.) покликало до створення оригінальної композиції. Тут автор виступив як виконавець флейтового соло. Твір будується на зображальній картинності, яка передана двома рівноправними музичнопросторовими площинами: електроакустичною партією, що відтворює небесну зоряну гармонію, та інструментальною, де за допомогою різних технічних ефектів змальовано безконечність космічних далей. Власне такими нестандартними авангардними засобами митець відтворив всеохоплюючий безмежний Всесвіт.

Ми вже згадували про створення С. Кругиковим багаточисленної музики до українських науково- 


\section{ТВОРЧА СПІВПРАЦЯ СВЯТОСЛАВА КРУТИКОВА ТА ГЕННАДІЯ САСЬКА}

В РАМКАХ ХІ МУЗИЧНОГО ФЕСТИВАЛЮ “СТРУНИ ДУШІ НАШОӤ”

популярних фільмів. Дрогобицька публіка мала нагоду на цій зустрічі познайомитися 3 кінострічкою "Вікна" режисера Миколи Бурноса. У зазначеній екранізації показано, як в період сучасного інформаційного сплеску стискається простір та прискорюється час на тлі екскурсу від традиційної культури до радикальних технічних змін. Музика Крутикова не тільки конкретизувала різнопланові сюжетні моменти, але й поглибила митецьку вартість фільму.

Завершуючи творчу зустріч, директор Інституту музичного мистецтва, професор Степан Дацюквисловив словаподяки композиторуС. Крутикову і наголосив на важливості таких заходів, оскільки вони $є$ яскравим виховним моментом та прикладом для майбутніх культурно-освітніх фахівців.

Ще однією артімпрезою у франковім краю стала персональна виставка художніх творів та світлин С. Крутикова, що відбулася 4 травня 2016 року в приміщені дрогобицького Палацу мистецтв. Представляючи авторські полотна (“Після концерту”, “Інтегральний краєвид”, “Гурзуф”, “Та, що наважилась” та інші), старший науковий працівник музею “Дрогобиччина” Надія Кікта наголосила, що в цих картинах переважає абстрактне малярство. Сам художник вважає власні витвори тим дзеркалом, у якому відбиваються не об'єкти, а індивідуальне світосприйняття. "У своїх роботах автор формалізує глобальні світові процеси, дає можливість осягнути механізми цих процесів. Пропонує усвідомлювати речі зсередини, розрізняти та порівнювати складові і розглядати як окремий всесвіт кожен, навіть, найменший елемент" [1], - зазначає в газетній публікації художниця Тетяна Думан.

Друга мистецька зустріч Святослава Крутикова відбулася 5 травня 2016 року 3 музичною громадою старовинного міста Стрия. Творчій інтелігенції було запропоновано прослухати композицію “Медитація пам'яті В. Раєвського для аудіофайлу та скрипки” у виконанні Іринея Турканика. Проникливо-чугливі скрипкові інтонації, що звучали на електронному звуковому тлі, викликали у слухачів молитовні асоціації. По-особливому ніжно був проінтерпретований викладачем СДМШ ім. О. Нижанківського Анжелою Вакс цикл “П'ять спогадів для клавесину”. Піаністка знайшла дуже ніжні звукові барви, які вияскравили романтичні програмні назви частин, а композитор постав перед слухачами як тонкий лірик. Кульмінацією зустрічі стало авторське виконання твору авангардного напрямку “Зоряна людина
Клим Чурюмов”. Партію флейти інтерпретував С. Крутиков. Ця електроакустична композиція вразила слухачів багаторівневою звуковою палітрою та різноплановими виконавськими манерами.

В інтерв’ю журналістці Любов Тиченко маестро зазначив: “Давно збирався до Стрия. До речі, тут жив мій родич Орест Рейслер, якого, на жаль, вже не має серед нас. Познайомитися 3 вашим містом випала нагода аж тепер. Після відвідин місцевих музеїв залишилися неймовірні враження. Вразило, 3 якою любов'ю та старанністю створені музейні експозиції. Скажу відверто, я закоханий в Стрий” $[6,3]$.

У листопаді 2016 року Музичний фестиваль “Струни душі нашої” гостинно приймав сучасного українського композитора, Заслуженого діяча мистецтв України, члена НСКУ, Лауреата премії ім. В. С. Косенка, Лауреата мистецької премії "Київ" ім. Артемія Веделя - Геннадія Саська. 20 жовтня 2016 року митець святкував своє 70-річчя. Власне ця ювілейна дата стала поштовхом до вшанування галицькою музичною громадськістю композиторської творчості одного з найпочесніших українських митців - “семидесятників”.

Маестро здобувши грунтовну музичну освіту (Донецьке музичне училище як піаніст, Київську державну консерваторію ім. П. Чайковського (клас композиції Левка Колодуба), працював на різних мистецьких ділянках: завідувачем музичної частини Київського театру російської драми ім. Лесі Українки, диригентом ансамблю Червонопрапорного Західного прикордонного округу, завідувачем редакції видавництва “Музична Україна”. На сьогоднішній день викладає в Київському Інститугі музики ім. Р.М. Глієра, а також одночасно є директором музичного видавництва “Гроно”. У творчому доробку композитора - симфонічні твори, вокальносимфонічні твори, мюзикли, композиції для органа, твори для, камерні твори для фортепіано, скрипки, віолончелі, музика до театральних вистав та мультфільмів (зокрема до мультфільму "Капітошка").

Фестивальне турне Г. Саська розпочалося 3 приїзду до старовинного міста Стрия 15 листопада 2016 року. Саме на сцені Стрийської дитячої музичної школи імені Остапа Нижанківського відбувся перший ювілейний концерт київського маестро. Мистецька акція була підготовлена членами Об'єднання піаністів-педагогів Стрийщини та за сприянням голови Дрогобицької організації НСКУ Володимира Грабовського. У музичній програмі свята прозвучала низка фортепіанних творів: “Фантазія для 
фортепіано"(викладач СДМШ ім. Остапа Нижанківського А. Вакс); дитячий цикл "Мозаїка" - “Синички за вікном” (3. Сов'як, уч. III класу СДМШ ім. О. Нижанківського, викл. М. Добош), “Веснянка” (Я. Когут, уч. IV класу СДМШ ім. О. Нижанківського, викл. О. Білик), “Перший пролісок" (С. Садова, уч. IVкласу СДМШ ім. О. Нижанківського, викл. О. Білик); альбом "Українські народні пісні узаписах Павла Тичини" - "На небі місяць, зіроньки сяють" (фортепіаннийдуетучнівСДМШім.О.Нижанківського у складі Б. Лабусевич (уч II класу) та С. Лабусевич (уч. III класу), викладачі С. Дорожкіна та Т. Дорожкіна), “Та годі ж тобі сивий кінь” (фортепіанний дует учнів Стрийської хорової школи “Щедрик” у складі К. Корпало та О. Корпало, викл. О. Штурко), “Казала дівчина, казала" (I. Мартинів, уч. VI класу Стрийської дитячої щколи мистецтв, викл. М. Бойчук); джазові цикли _“Граю джаз” -“Блюз” (Б. Павловська, уч. V класу СДШМ, викл. Р. Романищин), “Джазвальс” (виконує Я. Петринець, студент I курсу Дрогобицького державного музичного училища імені В. Барвінського, викл. О. Штурко), "Регтайм" (М. Проців, уч. VII класу СДМШ ім. О Нижанківського, викл. А. Вакс). "Граю джаз-2!” - “Bossa nova” (Д. Кравець, уч.VI класу СДМШ ім. О. Нижанківського, викл. І. Шваб); сюїта“Відгомін століть”-“Бабин торжок”(Ю.Крилата, випускниця СДМШ ім. О. Нижанківського, викл. Н. Нев'ядомська), “Свято на Всеволодовім пагорбі” (Х. Греб, студентка IV курсу Інституту музичного мистецтва Дрогобицького державного педагогічного університету імені Івана Франка, клас доцента У. Молчко).

Чарівні вокальні композиції Геннадія Саська 3 мультфільму “Капітошка” припали до душі юним співакам з Стрийської дитячої музичної школи ім. О. Нижанківського, а саме - "Пісенька Дощика" 3 м/ф “Капітошка” виконала С. Гірник, уч. II класу (викл. І. Віновська-Жужевич, концертмейстер M. Добош) та "Пісенька Капітошки" 3 м/ф "Капітошка" виконала Ю. Заверуха, уч. IV класу (викл. О. Винницька, концертмейстер О. Загорянська).

Розповідь-представлення супроводжувалася музикознавчими коментарями доцента ДДПУ ім. I. Франка, голови Об'єднання піаністів-педагогів Стрийщини, завідувача фортепіанним відділом СДШМ Уляни Молчко.

Стрийська мистецька громадськість мала унікальну нагоду прослухати авторське виконання п’єс “Весняні хороводи на Болонії”, “Софія Київська" з циклу “Відгомін століть.

16 листопада 2016 року в актовій залі Дрогобицького державного педагогічного університету ім. І. Франка відбулася друга ювілейна творча зустріч Г. Саська та його дружини, кандидата мистецтвознавства, відповідального секретаря Національної спілки композиторів України Тамари Невінчаної з викладачами та студентами навчально-наукового інституту музичного мистецтва Франкового вузу. Нею була виголошена цікава та змістовна доповідь на тему "Розвиток української музики доби Незалежності”.

Друга частина заходу була присвячена творчості Геннадія Саська. У студентському виконанні прозвучали твори “Джаз-вальс" і “Регтайм” (Я. Петринець, студент Дрогобицького державного музичного училища ім. В. Барвінського, викл. О. Штурко); та імпровізації: імпровізація на тему "Bossa nova” (О. Красівська, студентка III курсу, навчально-наукового інституту музичного мистецтва ДДПУ ім. І. Франка, клас доцента О. Німилович) та імпровізації на теми Г. Саська “Блюз” і “Регтайм” (С. Сов’як, студент I курсу навчально-наукового інституту музичного мистецтва ДДПУ ім. I Франка, клас доцента Л. Філоненка).

Приємним сюрпризом для слухачів стала презентація п’єс “Балада” та “Бугі-вугі” із збірки “Граю джаз - 2!” у високопрофесійному та технічно досконалому виконанні самого композитора.

Творчу зустріч продовжили на сцені Дрогобицького державного музичного училища імені В. Барвінського. Туг прозвучали: хоровий твір Г. Саська "Сутінки" на вірші Ярослава Верещагіна у виконанні студентського хору (диригент, завідувач хоровим відділом Богдан Бондзяк), фортепіанні композиції із збірок: “Українські народні пісні у записах Павла Тичини" - “На небі місяць, зіроньки сяють” (фортепіанний дует учнів студії педпрактики ДДМУ ім. В. Барвінського М. Белз і В. Кузняк, викл. О. Денис), "Мозаїка" - "Мереживо" (студент I курсу А. Костів, викладач Л. Пагута), “Веснянка" (студ. I курсу В. Перловська, викл. І. Сосяк), “Арія” (студ. ІІ курсуЛ. Кіндратів, викл. С. Косинська), джазові п’єси - “Блюз” (учні студії педагогічного практики ДДМУ М. Ганусей, Ю. Фиштик, Д. Зелінський, викладачі Л. Кульчицький, О. Денис), “Джаз-вальс" (учениця студії педагогічного практики ДДМУ Я. Яциків, студент III курсу ДДМУ С. Ющенко, викладачі Л. Паращак, Д. Павлик), “Регтайм”(учні студії педагогічного практики ДДМУ Б. Гамар, А. Макогон, викл. В. Гамар, О. Терлецька-Фиштик), “Балада" (учениця студії педагогічного практики дДМУ Б. Гамар, викл. М. Бринич), “Bossa nova”(учениця 


\section{ТВОРЧА СПІВПРАЦЯ СВЯТОСЛАВА КРУТИКОВА ТА ГЕННАДІЯ САСЬКА В РАМКАХ ХІ МУЗИЧНОГО ФЕСТИВАЛЮ “СТРУНИ ДУШІ НАШОЇ”}

студії педагогічного практики ДДМУ Ю Фиштик, викл. О. Денис), “Бугі-вугі” (судент І курсу ДДМУ С. Павлів, викл. Л. Садова), альбом "Відгомін століть" - "Городище Кия" (учениця студії педагогічного практики ДДМУ А. Мішаніна, викл. М. Бринич), “Софія Київська" (викладачметодист А. Мішаніна), “Бабин торжок” (студент II курсу ДДМУ Г. Домін, викл. Л. Садова), "Весняні хороводи на Болоніі” та "Аскольдова могила” (студент I курсу В. Коваленко, викл. Л. Садова), "Свято на Всеволодовім погорбі" (студентка II курсу ДДМУ С. Ек, викл. Л. Садова).

Студенти училища мали нагоду прослухати шість п’єс фортепіанного циклу “Весняні барви” в інтерпретації композитора. Виконання відзначалося багатством імпресіоністичних барв, пейзажною колористикою, професійною піаністичною майстерністю.

Завершився ювілейний фестиваль-тур Г. Саська концертом у Трускавецькій дитячій школі мистецтв ім. Романа Савицького.

Висновок. Отож, зустрічі київських композиторів С. Крутикова і Г. Саська в Галичині показали динамічний творчий процес митців, який проходить в координатах духовного звільнення, що забезпечує створення сучасних, національних, мистецько-якісних культурних цінностей.

\section{ЛІТЕРАТУРА}

1. Думан Т. До уваги поціновувачів абстрактного мистецтва [Електронний ресурс] / Тетяна Думан // Медіа Дрогобиччина. - Режим доступу: http:// www.drogmedia.net.ua/index.php/afisha/2526-douvahy-potsinovuvachiv-abstraktnoho-mystetstva.

2. Зинькевич Е. Неформат: о “человекоявлении" Святославе Крутикове [Електронний ресурс] / Елена Зинькевич. - Режим доступу: http:// www.gnesin-academy.ru/sites/default/files/docs/ Zinkevych.pdf

3. Корольчук О., Виткалов С. Фестивальна регіональна практика в проблемному ціннісному аспекті сучасної культурної ситуації / Ольга Корольчук, Сергій Виткалов // Українська культура: минуле, сучасне, шляхи розвитку: зб. наук. пр.: наук. зап. Рівнен. держ. гуманіст. ун-ту. - Вип. 21. Т. 1 / упор. В. Г. Виткалов; редкол.:
А. Г. Баканурський, С. В. Виткалов, О. М. Гончарова. - Рівне: РДГУ, 2015. - С. 113 - 117.

4. Німилович О. Фестиваль музики Геннадія Саська [Електронний ресурс] / Олександра Німилович. - Режим доступу: http:// composersukraine.org/index.php?id=2774

5. Степаненко М. Крутиков Святослав Леонтійович [Електронний ресурс] / Михайло Степаненко // Енциклопедія сучасної України. Режим доступу: http://esu.com.ua/search articles.php?id=2282

6. Тиченко Л. Барви таланту / Любов Тиченко // Гомін волі. - 2016. - 14 травня. - С. 3.

\section{REFERENCES}

1. Duman, T. (2016). Do uvahy potsinovuvachiv abstraktnoho mystetstva [To the attention of connoisseurs of abstract art]. Media Drohobychyna [Media Drogobichina]. Available at: http:// www.drogmedia.net.ua/index.php/afisha/2526-douvahy-potsinovuvachiv-abstraktnoho-mystetstva [in Ukrainian].

2. Zinkevich, E. (2010). Neformat: o "chelovekoyavlenii" Svyatoslave Krutikove [Informality: about the "human manifestation" of Svyatoslav Krutikov]. Available at: http://www.gnesin-academy.ru/ sites/default/files/docs/Zinkevych.pdf [in Russian].

3. Korolchuk O. \& Vytkalov S. (2015). Festyvalna rehionalna praktyka $\mathrm{v}$ problemnomu tsinnisnomu aspekti suchasnoi kulturnoi sytuatsii [Festival of the reginal practice in the problematic cultural aspect of the successful cultural situation]. Ukrainian Culture: at the latest, at the proper time, hints rozvitka: $z b$. sciences. pr .: of sciences. app. Rivne. hold. humanist. un-tu., issue. 21, vol. 1, pp. 113 - 117. [in Ukrainian].

4. Nimylovych, O. (2016). Festyval muzyky Hennadiia Saska [Music Festival Gennady Sashka]. Available at: http://composersukraine.org/ index.php?id=2774 [in Ukrainian].

5. Stepanenko, M. (2014). Krutykov Sviatoslav [Krutikov Svyatoslav Leontievich]. Encyclopedia of the modern Ukraine. Available at: http://esu.com.ua/ search_articles.php?id=2282[in Ukrainian].

6. Tychenko, L. (2016). Barvi talantu [Colors of talent]. Homin of the freedom, 14 may, p.3. [in Ukrainian].

Стаття надійшла до редакції 27.06.2018

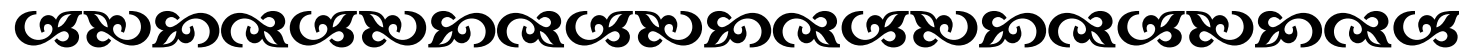

“ТІворець художнъого твору майбутнъого є не хто інший, якхудожниктеперішнього часу”. Вагнер Pixapd

німецький композитор

\section{G58080605}

